\title{
THE EVOLUTION OF FORMALISM IN PAINTINGS OF THE 18TH CENTURY TO 20 IN EUROPE, AND ITS IMPACT ON THE ARCHITECTURE IN THE EARLY 2OTH CENTURY
}

\author{
Aliakbar Akbari \\ Department of Architecture and Urbanism, Qazvin Branch, Islamic Azad University, Qazvin, Iran \\ Amir Haghjou \\ Corresponding Author, Department of Art and Architecture, Shabestar Branch, Islamic Azad \\ University, Shabestar, Iran \\ Sima Ebrahimi \\ Department of Architecture and Urbanism, Qazvin Branch, Islamic Azad University, Qazvin, Iran
}

\begin{abstract}
Painting was not copied from natural elements, and the painter brought his reading of nature on his canvas through his inner feelings. Abstract art, which was quite formalistic manner, was at a mean for achieving this artist's desire. Abstract art in paintings has begun from expressionistic tendencies of the 18th century in Europe, William Turner is considered as the initiator of this movement, his recall from nature was beyond the mere illustration. In the following of this abstractionism path in painting, Impressionism and Cubism can be noted and Mondrian can be named, as the accomplisher of this movement. Mondriani is the creator of Neoplastism and was effective in the De Style movement. The main objective of this study is to evaluate the evolution of formalism in Europe 18 to 20 century painting. The most important question of this research is that, what is the impact of the formalism process in painting on distinguished works of modern architecture in the early 20th century. To answer this question, theoretical framework of the research was based on a separate survey each painter in his radical abstraction moving, and his effect on De Stijl movement, and the test was the result of the study in case samples of modern architecture's index. The research method was descriptive-analytical and historical-interpretation and statistical population was 3 works from modern style architecture. The research results can be mentioned to De Stijl movement influence, as the main axis of abstract art in architecture, from Mondrian and former abstract painters and see the result of this influence in modern architecture.
\end{abstract}

Keywords: abstract-oriented, impressionism - Cubism - De Stijl - form oriented

\section{INTRODUCTION}

Abstract art, with all various aims and loyalty to the state of human nature, is a mean to express the new views of the artist. The art, by providing new means of expression, enables the free mind of the painter, to reset the visual concept, and achieving a new order of reality. Painter, to explore his intricacies of the unconscious, searches for the hidden soul of the objects and the truth hidden from their appearance, and by reaching a pure geometric form, expresses the internal and purest concepts. From the perspective of an abstract painter, forms that are in any combination are the simplest shapes in reduction of visual fields. Because any form, is much easier and more organized, and easier to see and understand, in this way, he finds the pure geometry value in the abstract image. 
Artistic developments of the eighteenth century to the twenty in Europe are affected by impartial, objective and rational, classical-oriented attitude of contrast and realists, on the one hand, and emotional, subjective and irrational attitude of romanticism and Symbolist, on the other. This opposition is also clearly evident in the early modern art,: Manet, Degas, Monet, Seurat Vszan are representatives of the first attitude and Van Gogh, Gauguin, Munch and Ansouri are representative of the second approach. But, while artists of the nineteenth century, generally, tend to polarization of this contrast, the modernist artists seek to combine the two approaches and are working to give both issues _ the real, true and correct on the one hand, and the essence and the true meaning of the universe on the other hand _ a unique and the same answer. This effort is concerned the new paradigm: the belief in the inherent law and the fundamental unity of all existence require the development of an inclusive Henry's law, which provide the sensual and the spiritual unity, the real and the ideal, in a homogeneous form (Bekola, 2008: 17).

The source of modern art can be studied from different angles. However, it seems the development of abstract art in the early twentieth century is one of the most important origins. Undoubtedly, the abstract art is the most important achievement of modern art. The significance of this success is not certainly less than the Industrial Revolution. The abstract art promises clearly the dawn of a new era in the realm of aesthetics (Bani Masoud., 2010: 267).

Abstract art is actually quite formalistic manner that emerged from within the expressionist tendencies, and became the most pure modernist (ibid.).

The most important issue of this research is the effect of abstract art evolution in painting and the move to an entirely formalistic manner, and using this method in the architectural works in modern style. The evolution begins in the painting of William Turner, nature-oriented painter of the eighteenth century and continues to Mondrian of the twentieth century.

This research necessity was specifying the form of abstract art as the source of modern art in painters' works and showing abstract painters' trends in early twentieth-century toward the occult sciences.

\section{RESEARCH BACKGROUND}

Previous research related to this topic can be divided into two categories:

1- The books that are related to the spiritual evolution of abstract art in paintings from 18-20 century Europe:

- Books and encyclopedias about art history, books, such as, art history of Ernst Gambryj, Austria historian as well as art encyclopedia (painting, sculpture and graphic art) and Royin Pakbaz work.

- Resources that are in the case of modernist art, such as the history of modern art: painting, sculpture and architecture in the twentieth century for Arnason and modernism art of Sandra Bokula.

2. The books that are related to the analysis of modern architecture special works:

- Modern architectural book from 1900 works of William J.R. Kertis, in 3 parts and 24 chapters. Part I: Foundation of Modern Architecture. The second part: the crystallization of modern architecture between the two world wars. Part III: transformation and expansion of modern architecture after 1940.

Submit Date: 21.06.2016, Acceptance Date: 20.07.2016, DOI NO: 10.7456/1060AGSE/043 Copyright $(C)$ The Turkish Online Journal of Design, Art and Communication 
- The book "twenty buildings that every architect should know" by Simon Unwin, who has reviewed and analyzed the twenty outstanding works of architectures in it.

\section{THEORETICAL FRAMEWORK OF ARTICLE:}

Traces of the influence of abstract paintings of Mondrian and Malevich or Vendsburg in the works of modern architecture can be observed in other studies or books related to the history of modern architecture. However, having this influence been without any introduction or other related topics? The theoretical framework of this paper was started with the fundamental question for the researchers. A transformation happened following the Renaissance painting, by William Turner and this promise was a new movement in the abstract painting. Formalism movement process in the works of these painters is a part of the theoretical structure of this study, which continues with examining the painter and his style in painting, and the completing of this move was desired to Mondrian. Mondrian influence, as a supplement to the path of religious- mystical movements of his career and the condition he has lived in it, has been brought in the theoretical structure of this paper. This formalism movement to the architecture was done by the movement of De Stijl and Mondrian. In the final part of the research, we have reviewed the desired formalism in special works of modern architecture of the 20th century and conclusions about the effectiveness of these works have been extracted with formalism movement in paintings' works.

Mondrian as the emergence of form accomplisher and pure color on canvas painting that could extend this artistic approach in painting to architecture. In addition, the result of it was the works like Schroeder house that was completely surrounded in the form and structure of the desired artistic movement. Other important works of modern architecture were affected by the formalism of paintings from the 18th century to 20 Europe, to the Barcelona Pavilion and Fallingwater. 


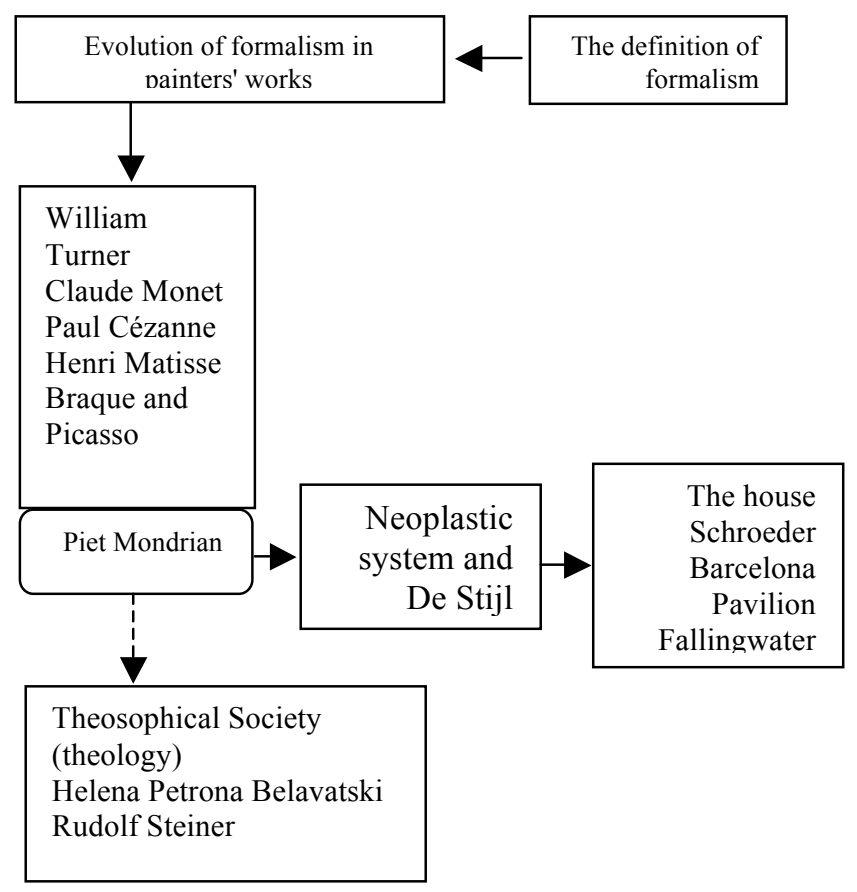

Diagram of theoretical framework

\begin{abstract}
IONISM AND FORMALISM:
\end{abstract}
Abstractionism is an embodying art with the fundamental and general characteristics of organisms and objects and ignoring visual effects and specific details of each of them. Abstractionism is a modern manner that has learned the art world from 1910 to the present, and its aim is to create works of imitation representation of the evident world. This movement (also called the art of representation, and in the advanced process it is also known as a non-object art) is based on the use of art elements of line, surface, volume, color, space, texture, to create a work that is a new visual experience in terms of each observer (Saba, 2005: 232).

Formalism is an action or doctrine that is emphasized in the form or formal structure. The term was common from 1920 with the group research from Russian writers, including Victor Shelosky, about the characteristics of the stylistic and formal structure of literary works. They were called formalist, because simply they have studied the form. Russian formalists have considered the literature-and in particular poem as special language and contrary to the common language and have limited the literary criticism in the same literary language framework. According to them, any attempt to analyze the content of literary work will force the critic into areas of non-literary, for example, psychology or sociology (Pakbaz, 1999: 343).

In the visual arts, unlike literature, the term does not have a principle-based application and so sometimes removing the subject, any misrepresentation, or abstract in art is considered careless of "formalism". In this regard, the following definition can be proposed: formalism is the use of contracts that only clear a formal look of a work (while these contracts were originally created to provide certain content). This special emphasis on form-no matter the content- can be found both in the abstract works and naturalism works (ibid: 343 ) 


\section{TH-20TH CENTURY PAINTERS IN EUROPE}

\section{TURNER: A REPRESENTATION OF NATURE, BEYOND MERE ILLUSTRATION}

William Turner (English painter, 1775-1851), because of his innovations, is considered as one of the most important European scenic. In addition to the sea and scenic natural landscapes, he has also painted historical themes, and in these curtains, his romantic tendency becomes more obvious (Pakbaz, 1999: 161).

The last stage of his artistic development (1830-1848) was the follow-up searches in the world of light and color. In the works of this period, the subject became unimportant against color composition. He was seeking a visual equivalent for non-visual set of emotions. Storms rotate of the brush, bright colors and abstract shapes reveal the poetic theme of his paintings, and so, the descriptive allusions reduce to the secondary factors (eg blizzard 1842). His semi-abstract works are called "painted fumes". Turner's attention to the effects of light, later affects Impressionist paintersespecially Monet and Pissarro that saw his works in 1870 in London. Perhaps, it can be said that, his work in terms of passion, heat and technical freedom exceed from impressionism to be related to expressionism in the twentieth century (ibid: 163).

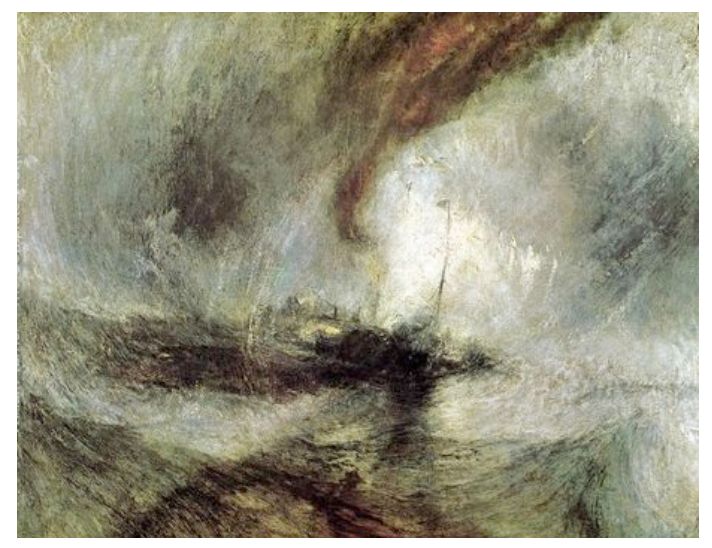

Picture 2 - blizzard -1842Source: www.william-turner.org

Turner's passionate and romantic representations of nature can be considered a form of escape from reality. However, purely painterly behavior, the use of rhythm, form, light and color to emotions in nature and the forces give improvisation gives special impromptu that is definitely beyond mere illustration. Turner's paintings do not carry the illusion of an accident; they have been an accident. His paintings give idea visualization that does not announce it. In this respect, Turner goes beyond the boundaries of the idealism of his contemporaries, like Delacroix, and will be placed in the row of the great pioneers of modernism (Bekola, 1998: 78).

\section{CLAUDE MONET, THE IMPRESSIONIST AND LIGHT CONCERNED}

The term Impressionism was a Louis Laurie achievement, an unkind critic of the journal "commotion" that has used the appropriate label inspired by one of Claude Monet's paintings about the experience "unconventional" in the Nadar Gallery, the famous photographer. As the painting was as a light blue net infiltrated of red-pink rising sun. Colors reflection in the water was 
representative of short and sparse strokes of the brush. Main impressionist - Monet, Auguste Renoir, Alfred Sisleh, as well as for several Paul Cézanne and Pisaro- have not much interest in scientific ideas about light and color and their atteintion had been more on the simple experience yet a nature that was drowned in sun-rich and glorious or a nature in the eternal and mysterious light in the morning or evening. (Arnason, 2004: 29).

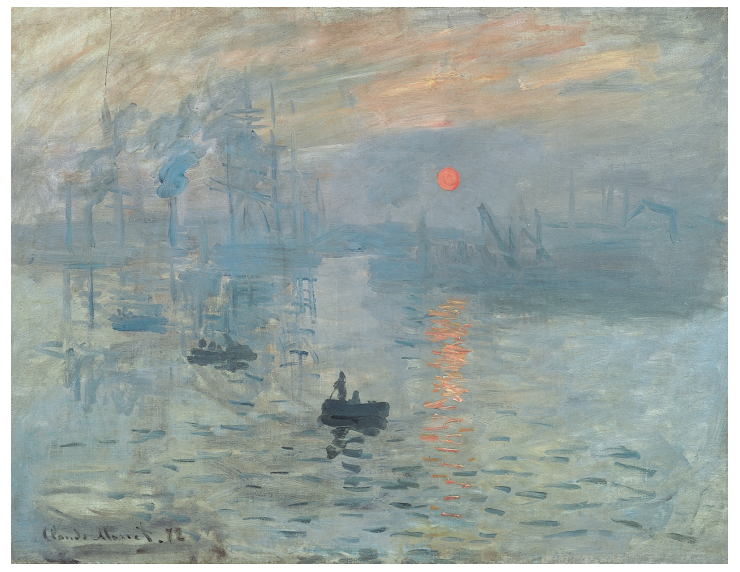

Picture 3 - Receive from sunrise, Claude

MonetSource: www.william-turner.org

The time had come, that painting is no longer merely, or even primarily, an imitation of the natural elements. Monet in Argenteuil Bridge has ordered all his elements, in a detailed network. He has blocked the background with horizontal mass of trees and bridge buildings. Brush strokes are temporary and most of the water level may induce, the impact of limited and low depth, and background has a state of colored areas, which are all parallel to the surface of the image. In this work, Impressionism can be taken into account as the ultimate refinement of visual realism, namely the description of visual reality, but not so simple that will be an imposing appearance of the natural objects, but as an endless metaphor of sunshine and shadow, reflection of water, and the role of clouds moving across the sky (ibid: 30 ).

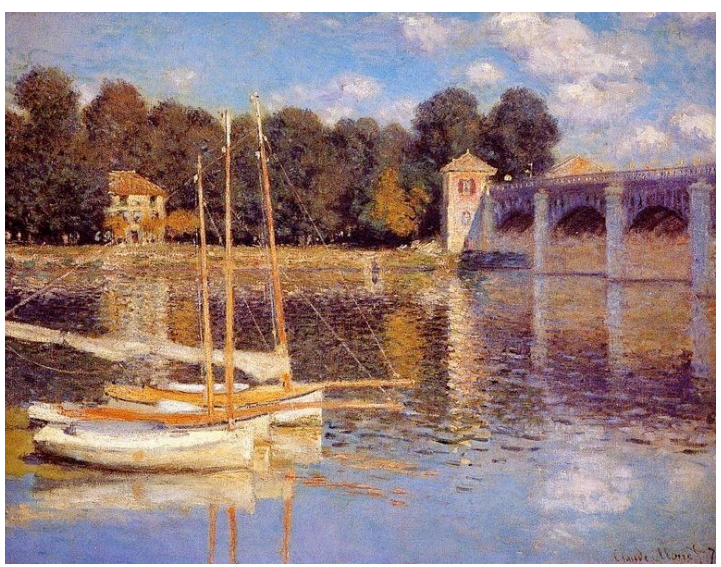

Picture 4 - the bridge Argenteuil, Claude

Kone Source: www.william-turner.org 
In Monet paintings, nature loses its objective nature and turns into the flood of sensory effects. Painterly rendering of the visual experience is the starting point of impressionist (Bekola, 1998: 108).

In impressionism, material qualities of painting decay and become a mere "impression" (ibid.). Impressionists use pure colors in the firm and dense layer (undiluted), composed of numerous tiny and uniform pen strokes, so that any pen stroke makes a unified single color. The interplay of these innumerable elements of color and same size causes the vibration of paintings and creates illuminated spaces rich of a color that is the character of Impressionist art (Bekola, 1998: 109). Impressionist teaches carol to painting, and makes the painter a musician. Adding the music dimension to painting - as "the liberation of color" - no doubt is considered the most important achievement of impressionism (ibid: 111).

Impressionists are claiming an independent identity of painting were created as an object that has its value, with its own structure and rules apart from what can have as the depth of view or imitation of man and nature. So, finally, the impressionist can be considered as an ending point of a realist tradition in deep representative Renaissance and the important beginning of the discovery in the twentieth century of abstract paintings and Cubism amazing color modes (Arnason, 2004: 31).

\section{PAUL CÉZANNE AND PRIORITY OF COMBINATION}

Cézanne's art is the art of composition. His insight about the unity of the image has a deep and lasting influence on the concept of modern art (Bekola, 2008: 115). In order to emphasize on the flatness of the picture, Cezanne put aside the classical single-point linear perspective, created depth in his paintings through the layers of overlapping, and intertwined. He, instead of reducing any surface into complementary colors and any line into single stroke pens like the Impressionists, converted the objects to same colored spheres that are limited with clear boundary lines or darker or brighter neighboring levels. He, unlike the Impressionists, has emphasized the material density and strength of the evident reality and has cleared the essentially cubic structure of its components (ibid: 117).

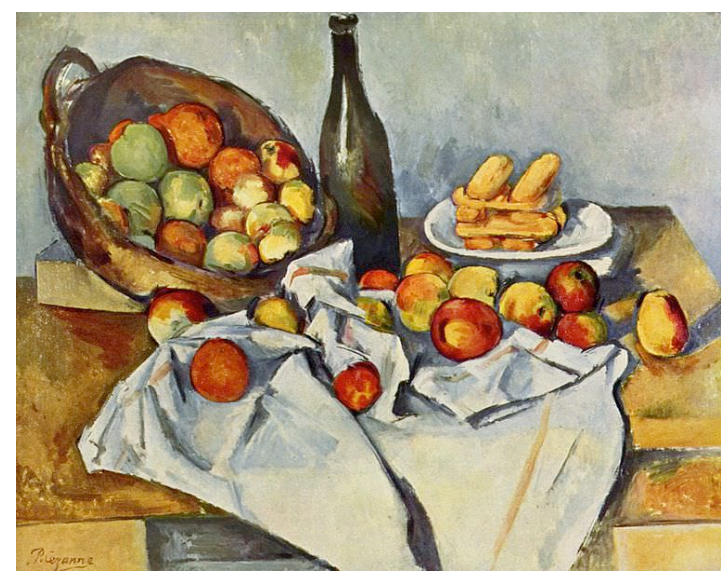

Picture 6 - Fruit Basket, 1895, Paul Cezanne

Source: www.william-turner.org 
Cezanne extends finely brush strokes of the Impressionists, and specifies the vertical, horizontal and diagonal directions. His brush strokes become regular patterns or energy fields due to the effect of parallel layers of paint, frequent and tight together and make different shades of color and contrast in conjunction with each other, which are woven together (Schmidt, 1976: 90).

\section{HENNRI MATISSE}

Hennri Matisse (a French painter, body builder, designer and printer, 1869-1954), because of his innovation, and his influence on contemporaries, is one of the most important artists of the twentieth century. The historical significance of his discoveries in the field of pure color can be considered in the form of cubism in the liberation of form from the shackles of objective representation (Pakbaz, 1999: 494-495).

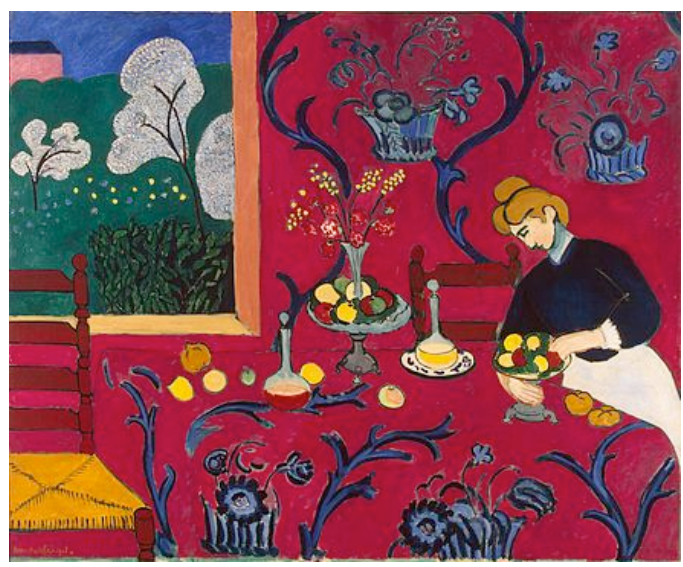

Image 7 - The Red Room, 1908, Matisse

Source: www.william-turner.org

Matisse, in leaving the 'feeling', and Searching image Tools "pure", is similar to Mondrian. For example, he says: Colors and lines are power and the mystery of creation lies in the play and balance of these forces. However, he is alien to the mentality of Puritani and Calvin Mondrian. Matisse is not searching for an abstract truth, but harmony with life and the world. He, unlike Matisse, does not ignore artifacts and nature, but also he seeks to establish new relationships with them. Like the Impressionists, he does not look at nature from the outside. Not like Seurat, he wants to receive an analysis of the nature and not as Cézanne, he seeks to disclose the structure of nature, but he wants to capture it and make it his own. According to him, the artist attracts the outside world in self, so that the object of his design will be a part of him, to make him inner and could bring it across the canvas as his own creation. (Bukola, 2008: 185).

\section{GEORGE BRAQUE, PABLO PICASSO AND THE FORM CONCERN}

Faced with African sculpture around 1906, showing Cézanne's oeuvre in 1907 are the main factors pushing George Braque and Pablo Picasso to invent cubism between 1907 and 1914. ${ }^{1}$ The two

\footnotetext{
${ }^{1}$ In the case of Picasso, Henri Rousseau's influence is considerable. The first experiences "cubist" of Picasso
} was influenced by the material brevity in Gomrogchi. 
artists, in two stages of development, make the drawing from his previous links to external reality free and create art and theory prerequisites of a self-order art (Bokola, 2008: 169).

In the first phase of cubism development, known as "analytic", Braque and Picasso took Cezanne structural approach regardless of its color rendering and by limiting themselves to brown and ocher, green, and gray, insist more on their form. By body and space harmonic analysis to the cubist chips, step by step, they deconstruction the shape of things and create a kind of crystal independent of the object structure, if their paintings lose the conventional image readability and become formal self format (same).

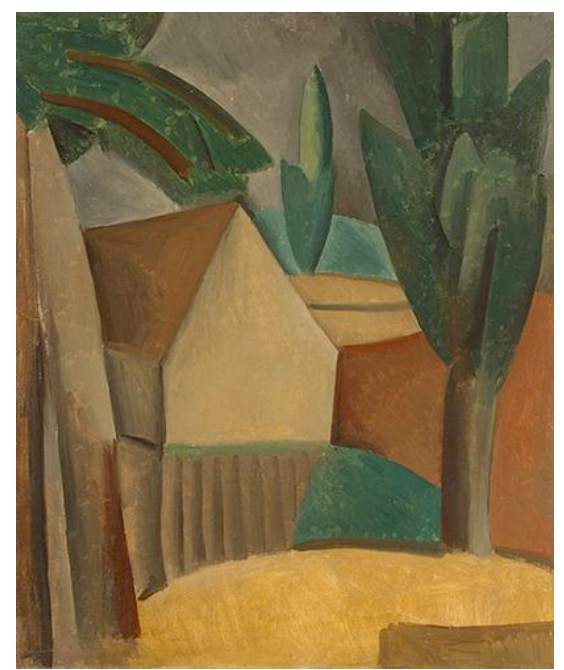

Image 8 - A house in the garden, 1908, Picasso Source: www.wikiart.org

With cubism, image equipment modernization course, that was started with Impressionism, ends. While, Seurat broke the natural light into the whole net films, to save the color and gives musical resonance to it. Braque and Picasso have disintegrated the objects to volume and geometric elements, and have self-regulated the form and have given mobility to it (Schmidt, 1976: 171).

In the second phase of cubism development, known as the "hybrid" _ during which Spanish Juan Gris joined Braque and Picasso _ these two artists have simplified the structure of their paintings. Individual components of the composition are larger. Ijaz, contrast and more power will be emerged in lines and shapes. Variable formations of input, overlapping and often transparent levels involve the cubist effects of the previous stage (analysis). Picasso and Braque thanks to these levels of the inputs may mix the flatness with the image depth (Bokula, 2008: 170). 


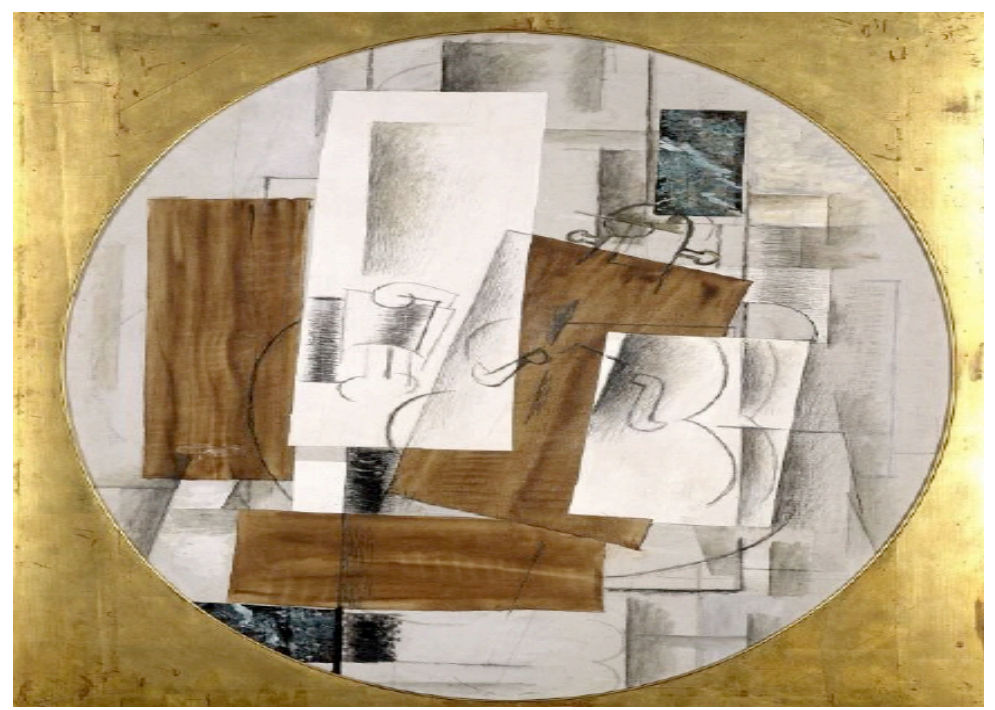

Figure 9 - Violin and Glass, 1914, Georges BraqueSource:

wrurur rrilinadis nor

\section{PIET MONDRIAN AND THE SPIRITUAL EFFECT}

Piet Mondrian (1872-1944 Dutch painter and theorist), as one of the leaders of geometric abstraction, had a broad and profound impact on art and modern architecture. Mondrian believed that the appearance of the object has always prevented a beautiful feeling, so it should be removed from the image (Pakbaz, 1999: 541).

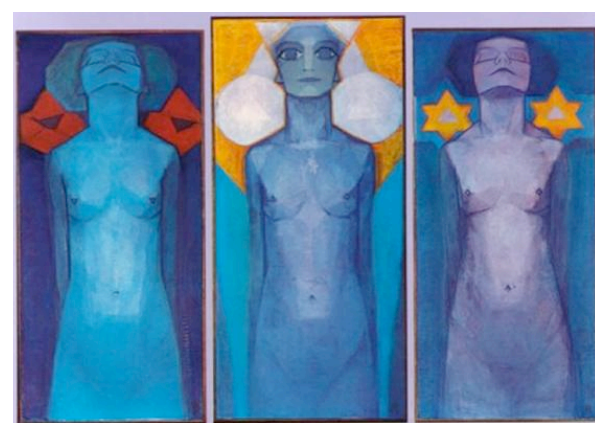

Figure 11 - Three rag Evolution, 1910, Mondrian

Courna. (Rulrols onne. 175)

Mondrian has studied works include the controversial book of Helena Petrovna Blavatsky secret congenial (that is along with her till the end of life), the writings of Rudolf Steiner, and the book of great seekers Edward Shure and in 1909, he has joined the Theosophical Society ${ }^{2}$ (Bukola, 2008:

${ }^{2}$ Theosophical Society (theology) was from the most influential religious movements, that Helena Petronablavatsky has founded it in 1875 , in New York. Secret Disposition was the most important book of Blavatsky, consisting of five hundred pages, was published in 1888. In this book, he has mixed all kinds of occult sciences, alchemy, spirit, belief and mystical elements of Hindi, Persian, Hebrew and Gnosticism, to create a "cult" that claimed the mixture of common great religions essence of the world, and philosophical systems of all time (Blavatsky (1888), vol. 2, p. 294). 
175 ). Mondrian symbolism period has lasted between 1905 and 1911. The most significant of his mystical thought in three rags drawing of "evolution" can be observed, which is an attempt to show the development and the individual growth in the sight of the "Halo" (ibid: 171).

A Mondrian encounter with Cubism is a revelation and a discovery. At once, he has found out about the art capacity of this visual approach, has found his expressive possibilities of science and tangible main interests and common-law and fundamental unity of the universe. Thus, his symbolic step of his works ended suddenly. Mondrian, a few months after this change of view, has stayed in Paris to study cubism and soon, his style of painting takes some distance from previous patterns and an evolution will happen that its result was the emergence of "Classic" style. In flashbacks to 1937, he writes:

I gradually realized that Cubism is not embracing its logical consequences of its finding and does not extend the abstraction to the ultimate goal, which is the expression of pure reality. I believed that this reality would be realized through pure idea. The pure notion in its natural state is not bound to feel and think. [...] The natural forms change, while the reality remains constant. Creating pure fact, in this way, requires reducing natural forms to fixed components of form, and the change of natural color to the primary colors (Bukola, 2008: 176).

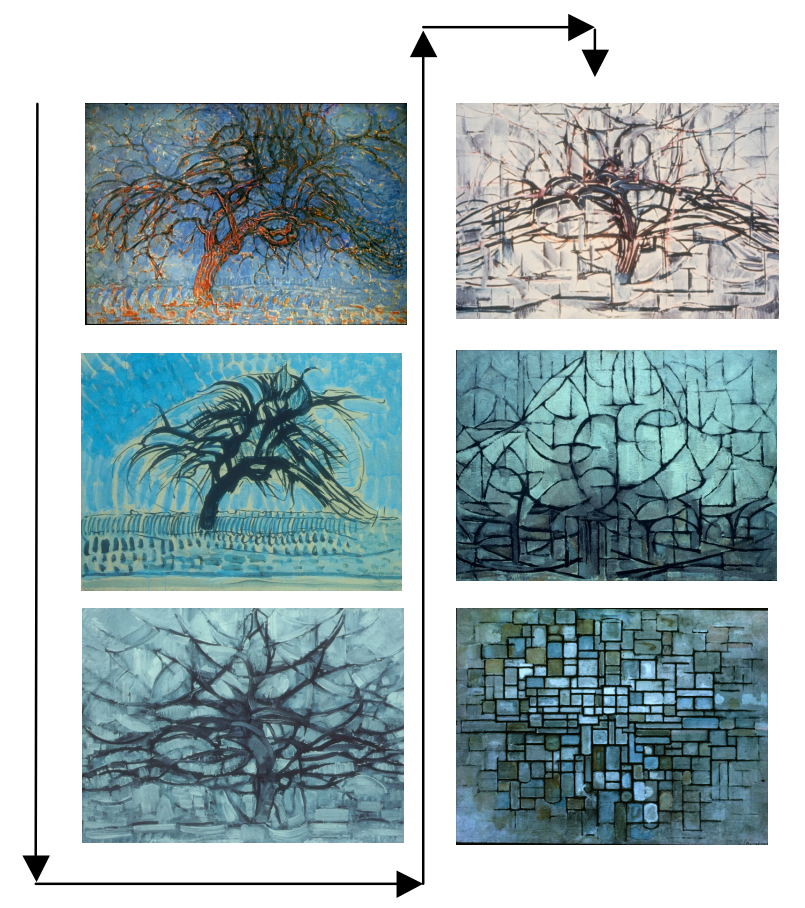

Figure 12 - reducing tree to abstract form,

Mondrian

Source: author

Rudolf Steiner was from the pioneers of the movement, that led a branch of German of the Association, from 1902 until his retirement (over the selection of Krishnamurti as the new teacher in the world). (Steiner (1994), pp. 14-15) 
In 1913, the first fully abstract paintings - have created floating structures consisting of vertical, horizontal and half-round lines: a system that is harmonious and more or less balanced that is an inductor of a sense of calm and dignity. Then the continuous process of simplification begins. Mondrian has eliminated gradually all the remained elements of "bother" (curved and diagonal lines and combination colors) from his work and from 1925, he has satisfied with the three elements of the design: white background, black vertical and horizontal bars, and three main shades of yellow, blue and red (ibid: 177).

Mondrian's later compositions, influenced by the fill pounding rhythm of shimmery neon lights, Dynamic New York City, and spicy rhythms of jazz, has colorful mosaics on their own (eg: boogieWoogie on Broadway -1943) (Pakbaz, 1999: 542 ).

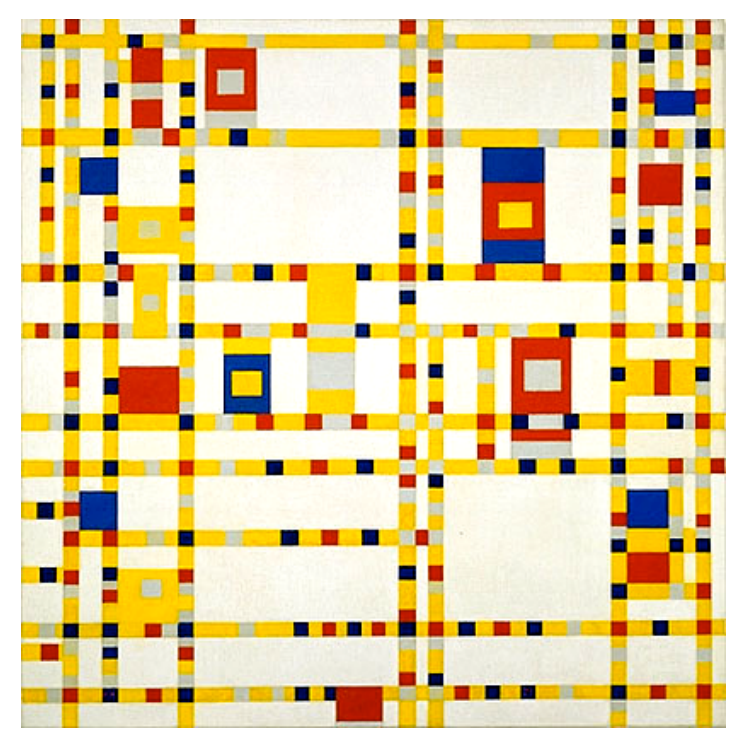

Pictures 13. Boogie - Woogie on Broadway, 1943, Mondrian

Source: (Bokola, 2008: 181).

Mondrian and De Stijl group and other movements such as Bauhaus have left logically proven aesthetic criteria that will be entirely cleared the appearance of the technical and industrial civilization in the twentieth century (Bokola, 2008: 183).

\begin{tabular}{|l|l|l|}
\hline \multicolumn{1}{|c|}{ Painter } & \multicolumn{1}{|c|}{ Approach in painting } & Sample works \\
\hline $\begin{array}{l}\text { William Turner } \\
(1851-1775)\end{array}$ & $\begin{array}{l}\text { - Romantic trend } \\
\text { - First simple impressions of the nature, continued follow- } \\
\text { up searches in the world of light and color } \\
\text { - To find a visual equivalent to a set of non-visual feelings } \\
\text { - passionate and romantic represented by nature, a kind of } \\
\text { escape from reality } \\
\text { - Visualize the thought in the picture rather than mere }\end{array}$ & $\begin{array}{l}\text { Snow blizzard } \\
\text { Venice, Sunrise }\end{array}$ \\
\hline
\end{tabular}




\begin{tabular}{|c|c|c|}
\hline & express & \\
\hline $\begin{array}{l}\text { Claude Monet } \\
(1926-1840)\end{array}$ & $\begin{array}{l}\text { - Describing the visual realities for endless metaphors from } \\
\text { the sun and shadow, water reflection and the role of moving } \\
\text { clouds } \\
\text { - The loss of objective nature and become a flood of } \\
\text { sensory effects } \\
\text { - One of the sense of light and color in painting } \\
\text { - Spaces full of light, color, color dumping } \\
\text { - The ending point of deep Renaissance reality tradition and } \\
\text { the beginning of the discovery of the } 20 \text { th century }\end{array}$ & $\begin{array}{l}\text { From sunrise } \\
\text { Argenteuil } \\
\text { Bridge }\end{array}$ \\
\hline $\begin{array}{l}\text { Paul Cézanne } \\
(1906-1839)\end{array}$ & $\begin{array}{l}\text { - Cézanne's art, the combines art } \\
\text { - Things turn into areas of similar color, which are limited } \\
\text { with certain boundary lines or darker or brighter with the } \\
\text { neighboring levels have been limited. (Crystallized form in } \\
\text { the drawings) }\end{array}$ & $\begin{array}{l}\text { fruit basket } \\
\text { Jadufan }\end{array}$ \\
\hline $\begin{array}{l}\text { Henri Matisse } \\
(1954-1869)\end{array}$ & $\begin{array}{l}\text { - Intense and brilliant colors are colors and lines of force } \\
\text { and the secret of creation lies in the play and the balance of } \\
\text { these forces }\end{array}$ & The Red Room \\
\hline $\begin{array}{ll}\text { Brock } & (1963- \\
1882) & \\
\text { Picasso } & (1973- \\
1881( & \end{array}$ & $\begin{array}{l}\text { - Works of art is not imaging, but it is making } \\
\text { - The shape of things will be deconstructed and a kind of } \\
\text { crystal structure independent of the object is created } \\
\text { - By analyzing objects into volume geometric elements they } \\
\text { have organized the form, and gave it mobility }\end{array}$ & $\begin{array}{l}\text { House in the } \\
\text { garden } \\
\text { Violin and Glass }\end{array}$ \\
\hline $\begin{array}{l}\text { Piet Mondrian } \\
\text { (1944-1872) }\end{array}$ & $\begin{array}{l}\text { - Removing the appearance image of the object from the } \\
\text { image because it prevents the feeling of beauty } \\
\text { - An abstract is extended to the ultimate goal, which is the } \\
\text { pure reality } \\
\text { - Reducing the natural forms to the fixed components of } \\
\text { form, and turning the natural color to the primary color } \\
\text { - Late composition: under the influence of tense rhythm in } \\
\text { shimmery lights of neon, dynamics New York City, fast } \\
\text { jazz music, they had colorful mosaics on their own. }\end{array}$ & $\begin{array}{l}\text { Three rags } \\
\text { evolution } \\
\text { Woogie Boogie } \\
\text { in Broadway }\end{array}$ \\
\hline
\end{tabular}

\section{DE STIJL}

Neo Plasticism movement was founded in the Netherlands in 1917 with the establishment of the magazine De Stijl (Style). Piet Mondrian introduced the term. He has proposed the Neo Plasticism 
theory and has created a great revolution in abstract art. Mondrian believed that art should be "denature", meaning it should be free from any representation relation with natural objects and their components and rely solely on abstract elements. To achieve this, Mondrian has limited the elements of an artistic composition to straight lines and right angles (ie horizontal and vertical relations to the framework of the panel) and has used the three primary colors (blue, red and yellow) and black and white and gray (Lyntn, 2003: 498).

In 1917, at the same time with Neo Platicism movement, the leaders of the journal De Stijl have published the opinions and views of Neo Platicism artists broadly, critics circle later called it "De Stijl". Artists of De Stijl movement were looking for balance and coordination rules, in a way that they can be applicable with artistic and social. The votes of the De Stijl movement artists has reached a considerable influence between the two world wars, but most especially as they had an influence on the architecture and design, especially on Bauhaus school to other arts (Bani Masoud, 2010: 271).

\begin{tabular}{|c|c|}
\hline Painters & Votes from the artistic works in the movement De Stijl \\
\hline William Turner & Visual equivalent for non-visual set of emotions. \\
\hline Claude Monet & $\begin{array}{l}\text { Loss of an objective nature and becomes the emotional } \\
\text { effects. } \\
\text { Illuminated spaces, rich in color, free of color }\end{array}$ \\
\hline Paul Cézanne & Combining art. \\
\hline Henri Matisse & Intense colors and brilliant, colors and lines of force. \\
\hline Braque and Picasso & Break the object into pieces and reassembled them. \\
\hline Mondrian & $\begin{array}{l}\text { An abstract will be developed to an ultimate goal, which is } \\
\text { the pure fact. } \\
\text { Natural color conversion to the primary color }\end{array}$ \\
\hline
\end{tabular}

\section{CASE EXAMPLES}

\section{- Schroder House}

The most important works of this movement in the architecture, the Schroder House can be cited. Gerrit Rietveld built the building in 1924 in Utrecht in the Netherlands that is the perfect job in the architecture of residential buildings. In the Schroeder house design, he has followed the original same principles that have used in making a chair, in 1917, meaning the decomposing it into pieces, and re-assembling it. The layout of the house was three-dimensional in Mondrian's paintings. It has 
none of the elements of weight, pressure, or stillness; all levels, as far as possible, are narrow and all are external and internal volumes are enclosed. Some levels, on the corner of the building have come together, and some as if they have slipped in space with each other. The ground plan of the house has the flexibility and single rooms are "integrated" with solid walls of glass, and part of the ceiling had been evicted in such a way as if they have no anchor. The central part of the building forehead ha has been removed from the facade and instead, a vertical scale plane has been formed that creates a dramatic effect, as if it is an independent component and weightless. In the view, the vertical and horizontal elements intersect and balance each other. The only Schroeder intricacy is simple steel tubes that are used as fences (Lamponiani, 2002: 51).

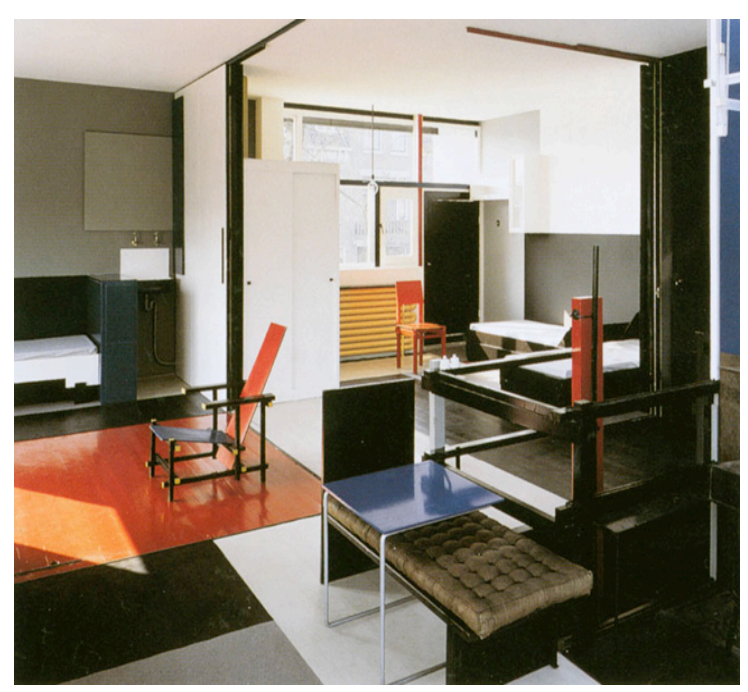

Figure 14 - the Schroder House (internal space),

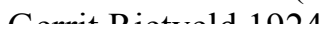

\section{- The Barcelona Pavilion}

In the book of "Architecture and its interpreation" wrote by J.P Bonta in 1979, the Barcelona Pavilion is used as an educational work in accordance with the thoughts in the book. Bonta has discussed about architecture criticism and displaying the relation between Miss Vanderohe's works and Netherland artists' artistic movement in 1920 named De Stijl in his several pages of his book. The impact of this group on minimalism attitude and providing the job with minimum components in Miss Vanderohe's works is clearly completed (Anvin, 2011:39).

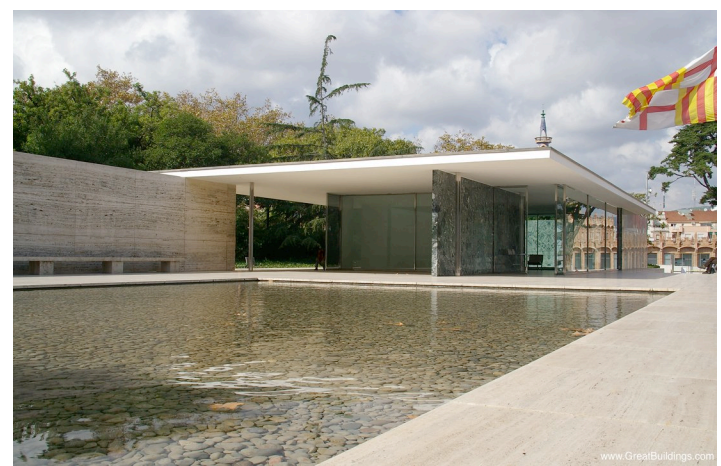

Submit Date: 21.06.2016, Acceptance Date: 20.07.2016, DOI NO: 10.7456/1060AGSE/043 Copyright $(C)$ The Turkish Online Journal of Design, Art and Communication 
In 1924, Miss Vanderohe wrote: "the creation of form in the formalism approach framework is something we seek to deny" and to continue, she emphasized on form issues for objectivity of an architectural work (like Barcelona Pavilion) in 1927 said: "I do not deny form; I do not disagree with limited the architecture in the form providing". The point that it seems Miss has tried to say is expressing each architectural project as an opportunity for reading and studying previous approaches, a search that considers the main detail and architect's job process ahead from a repeated response to achitectural issue. (Ibid:40)

This loge like the Schroder House, Bauhous buildings and Lokorbuzieh Villas will be a delicate solution for broader issues and common tool of its era. Historians pay their attention to the similarity of the map with Mondrian's paintings, verbal used of materials (the relation between Miss with new identity), simplicity of wall surfaces that represents Miss Vanderohe's tendency to coordinate unaffected surface from above to below, expresses the desire of Miss Vanderohe to unaffected fitness levels, from top to bottom, and have focused on the modernity and richness imagine of space with its floating Pages and uncertainties painterly fantasies (Curtis, 2003: 287).

\section{- Fallingwater House}

If it displays the body of Fallingwater house, only in the combined components of the plan (Image), identifying its relations, in the same way that is expressed in the ideas of 1920, "neoplastic" will be easily possible. For example, it is possible to mention the Schroeder's house, in the city of Utrecht in the Netherlands. Fallingwater house compares to the Schroeder house has less abstract in its structure, and of course, proportionally, it has more compatible with its surroundings. The plan of Fallingwater house, especially in its southern facade, emphasizes on the horizontal and natural layering of reefs around it and human movement, as well as openness to sunlight. In addition, Fallingwater house compared with the Schroeder house has more emphasis on its spread in three dimensions. In the discussed plan, it seems, architectural space, such as some boxes, is only connected to each other, while, in the spatial organization of Fallingwater house, this approach in the interior is provided both in the vertical and horizontal direction and is extended to the outdoors and landscape around the house (Unwin, 2011: 153).

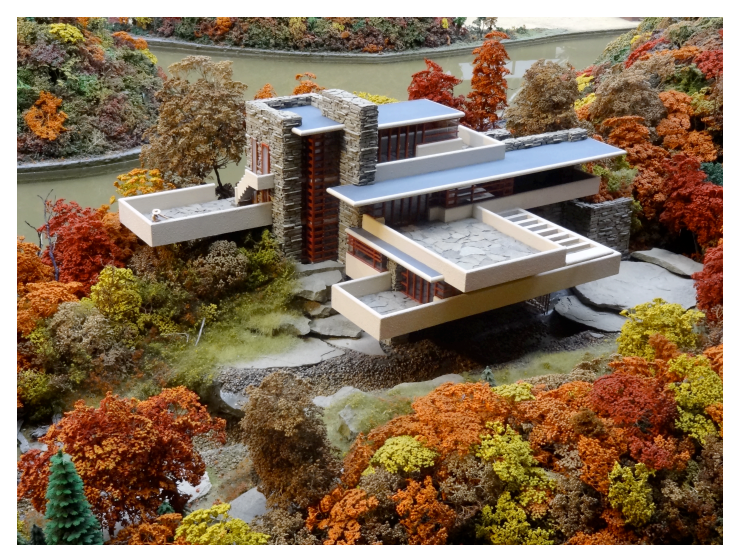




\begin{tabular}{|l|l|l|}
\hline Case examples & $\begin{array}{l}\text { Abstractionism - formalism - De Stijl - } \\
\text { neoplastisism } \\
\text { 1. Schroeder } \\
\text { house }\end{array}$ & $\begin{array}{l}\text { Analysis of the house into pieces and then } \\
\text { reassembling them (trace of the influence of } \\
\text { Cubism) } \\
\text { Design of the House is the equivalent to } \\
\text { three-dimensional Mondrian painting. }\end{array}$ \\
\hline $\begin{array}{l}\text { 2. The Barcelona } \\
\text { Pavilion }\end{array}$ & $\begin{array}{l}\text { Trying a pure form, for the objectivity } \\
\text { achieve an architectural work. } \\
\text { similarity of the Barcelona Pavilion plan } \\
\text { map, with paintings by Mondrian. } \\
\text { Modernization and richness imagine a } \\
\text { space with floating surfaces, like Mondrian } \\
\text { paintings. }\end{array}$ \\
$\begin{array}{l}\text { 3.Fallingwater } \\
\text { house }\end{array}$ & $\begin{array}{l}\text { Combining elements of the plan, such as } \\
\text { Mondrian's paintings. } \\
\text { has more compatible with its surroundings. }\end{array}$ \\
\hline
\end{tabular}

\section{CONCLUSION}

In the Renaissance, the art of painting has reached the realistic perfection with the invention of perspective and after this period, artists of the 18th century in Europe thought about the reality except what they observe in the nature and it was their reading out art of nature. The art was toward the formalism and abstractionism. This movement was started by William Turner and was finished with paintings by Mondrian that was a net movement of form and color. Mondrian lived under the influence of divine wisdom and New York, where he lived, and he achieved a mystical minimalism in his works. De Stijl movement and neoplastism theory were the gateway to this formalism to the architecture. The research results that were done on three works of modern architecture in the early 20th century, can be seen, that the movement of radical abstractionism in the painting directly inspired the Schroeder house. Barcelona Pavilion in the map Plan and floating pages of the volume and Fallingwater house, in combination of its Plan components were such as Mondrian's paintings.

On completion of the study, the minimalism of Russian literature and its impact on constructivist paintings and suprematism and their relationship from the viewpoint with modern architecture can be mentioned. 


\section{REFERENCES}

- Arnason, Yoruerdor Harvard, the history of modern art: painting, sculpture and architecture in the twentieth century, translation Mustafa Islamiye, Tehran: Agah Publishing, 2004.

- Unwin, Simon (2011), twenty buildings that each architects must recognize, translator Masoud Habibi and Hussein Mohammad Rasuli, Tehran: Publication peshotanu.

- Bani Masoud, Amir, West Architecture: Origins and Concepts, Tehran century architecture Art Publishing, 2010.

- Bokola, Sandro, modern art, translators: Rubin Pakbaz others, Tehran, contemporary culture, 2008.

- Pakbaz, Robin, Encyclopedia of art (painting, sculpture and graphic art), Tehran: Contemporary Culture Publishing, 1999.

- Saba, Siavash (2005), abstract art, Art Quarterly, Issue 63, Spring 2005, Pages: 232-243).

- Curtis, William (2003), modern architecture from the 1900s, translator Morteza Goudarzi, Tehran: Organization of Study and Compilation of Humanities Books (side).

- Gambryj, Ernest, art history, translated by Ali Ramin, Tehran: Reed Publishing, 2009 Sixth Edition.

- Lynten, N., 2003, Modern Art, translated by Ali Ramin, Tehran, Reed Publishing.

- Manyagv Lampvnyany, Vittorio, architecture and urban planning in the twentieth century; translation of Ladan E'tezadi, Tehran Shahid Beheshti University Press, 2007.

- Apollinaire, Guillaume, cubist painter, Witternborn Art Book, 1962.

- Bernard, Emile, Souvenirs sur Paul Cezanne et lrttres inedites, in: Mercure de France, 1980.

- Schmidt, Georg, Kleine Geschichte der Modernen Malerei, Basel: Friedr Reinhard, 1979. 